\title{
Take the leap: Early career exploration and the value of diverse library experience
}

\author{
Rachel Keiko Stark, MS, AHIP \\ California State University, Sacramento, CA
}

\begin{abstract}
Librarians who have worked in various types of libraries possess unique and valuable skills as a result of their experiences. Librarians should therefore be encouraged to apply to positions regardless of previous experience in a specific type of library, as their diversity of skills will benefit the communities they serve.
\end{abstract}

Author Bio: Rachel Keiko Stark, MS, AHIP, recently left her position as a hospital librarian and is now a Health Sciences Librarian for a public university. She has previously worked as a librarian for a large public library system and for a private university.

Keywords: library, career, hiring, job mobility

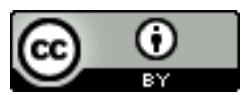

This is an Open Access article distributed under the terms of the Creative Commons Attribution 4.0 International License (http://creativecommons.org/licenses/by/4.0), which permits unrestricted use, distribution, and reproduction in any medium, provided the original work is properly cited. 
As an undergraduate, when I was exploring which professional librarian jobs were of possible interest to me, I was kindly informed that it was extremely difficult to move from one kind of library to another, and that I would need to decide what kind of librarian I wanted to be while I was still in graduate school. While I appreciated the advice, I felt that there was value in experiencing all kinds of libraries. I interned at a number of different libraries and archives, and I worked as a library assistant in public and academic libraries to gain varied experiences before completing my graduate degree. These experiences did not disprove the previous advice about choosing a specific kind of librarianship before I graduated, but they also did not help me decide what kind of library would be the best fit for me. When I graduated, I needed a full-time position to feed the student loan monster, so I made the decision to accept whatever full time position was offered to me regardless of what kind of library I would be working for.

My first full-time professional job was at a private university as a pharmacy and health sciences librarian who also was responsible for biology and chemistry. It was a wonderful experience, and not something for which I had studied at all in my graduate work. Yet, I wanted to explore and develop other skills and passions, so I took my first leap and decided to transition to a completely different type of library, applying for a youth services position in a large public library system. My passion for service and for connecting users with information crossed the barrier between academia and the public library in my application process. As I interviewed, I was able to articulate how my experiences in an academic environment, and specifically as a health sciences librarian, would positively inform my future as a youth services librarian. I was fortunate enough to be offered the opportunity to work in a library system that saw the potential of having someone with my experience in their program, and I was placed under the mentorship of an amazing librarian who helped me develop new skills. I was able to 
take my research with students in clinical programs and apply it to my new position. I saw how the public library was changing and adapting their youth programs to reflect the latest clinical and educational research, and I was able to fold those ideas into my programming. As an example, for story times I developed what I called "movements," where we channeled physical energy into a series of movements that reflected the natural world. We became seeds that grew, rivers that were full of fish and frogs, and winds that swept through the seasons. I was able to pull information on developmental research for parents, and discuss science project ideas with students in our library. I enjoyed my time in the public library setting, but I grew to understand that it wasn't the right fit for me and, more importantly, that someone else would be a better librarian for the organization. That's when I took my second leap and became a hospital librarian.

My experiences in the public library provided me with many wonderful skills, as well as more knowledge and practical experience in working with the general public, which was invaluable in my work as a hospital librarian. I was also able to pull from my experiences in both academic and public libraries to build new programming and deliver information in a way that was more accessible and often more entertaining. I gained invaluable skills in the hospital setting, but perhaps the most important thing I learned there was that my true passion is the health sciences, and that it is the area in which I want to spend my professional career.

I have specialized skills and I am able to use my professional experiences to better serve my community while growing as a professional. I know what I want to do, and I am learning where I want to be. I agree that it is difficult to move to a different kind of library, and I am still thankful to that kind librarian for helping me understand that fact, as it prepared me for just how different the professional experiences would be. That knowledge helped me understand that I had to be extremely clear about 
how my previous experiences would translate into my new positions during the entire application process. I had confidence that my resume and cover letter showed my professional experiences, my dedication to the profession, my commitment to excellence, and most importantly, that they highlighted how a wealth of experience could benefit the library to which I was applying. I was not afraid of rejection, but I was afraid that I was missing out on the library that would best suit my strengths and allow me to experience the most professional growth. My willingness to take those leaps allowed me to gain skills, insights, and experiences that are beneficial to me as a professional, and which also benefit the libraries I've served.

I urge new librarians to consider trying different kinds of librarianship and to not feel that they must stay in one type of a library or in one area of librarianship. I urge hiring committees and managers to follow the lead of my wonderful managers, who took a chance and allowed someone with different skills to come and work in their libraries, which benefits everyone involved. The skills and experiences librarians gain in various libraries, archives, and other institutions will allow them to develop new programs and new services, bring in new ideas and new ways of doing things, and engage community members in different ways. 